Ensino, Saúde e Ambiente - V6 (3), pp. 83-95, dez. 2013

\title{
ENSINO EM ENFERMAGEM E TOMADA DE DECISÃO: GUIDELINE 2015-2010
}

TEACHING IN NURSING AND DECISION MAKING: GUIDELINE 2015-2010

\author{
Danyele Aparecida ferreira da Silva; Evandro Floriano Gomes da Silva; \\ Adriana Rodrigues da Cruz e Márcia Ribeiro Braz \\ Centro de Ensino Superior de Valença \\ marciabraz2009@gmail.com
}

\begin{abstract}
RESUMO
O estudo tem por objetivo apontar o conhecimento de internos de Enfermagem sobre a atuação do enfermeiro durante uma PCR. Trata-se de um estudo exploratório descritivo, transversal, que foi realizado no curso de Enfermagem do Centro de Ensino Superior de Valença, na cidade de Valença, no estado do Rio de Janeiro. A amostra foi composta por 32 graduandos de enfermagem. Concluímos que, apesar de o curso ter uma disciplina que aborda a temática, com conteúdo teórico e prático, os acadêmicos apresentam déficit de conhecimento em relação às novas diretrizes do Guideline. Sugerimos que este conteúdo seja inserido em outras disciplinas como, por exemplo: Enfermagem na Saúde do Adulto e Enfermagem na Saúde da Criança.
\end{abstract}

Palavras-chave: Ensino em Enfermagem, Parada Cardiorrespiratória, Guideline

\begin{abstract}
This study aims to point the knowledge of the interns of Nursing about nurses' actions during a PCR. This is an exploratory, descriptive, cross-sectional, which was held in the course of Nursing of the Centro de Ensino Superior de Valença, in the city of Valença, Rio de Janeiro. The sample consisted of 32 nursing undergraduate students. Our conclusion is, although the course has a discipline that addresses the theme, with theoretical and practical content, the students have a knowledge deficit in relation to the orientations of the Guideline. We suggest that this content can be learned in other disciplines such as: Nursing in Adult Health and Nursing in Child Health.
\end{abstract}

Keywords: Education in Nursing, Cardiorespiratory Arrest, Guideline

\section{Introdução}

As Instituições de ensino superior que ofertam os Cursos de Enfermagem, buscando garantir um ensino de qualidade, têm norteado suas ações nas Diretrizes Curriculares Nacionais, da Graduação em Enfermagem aprovada pelo Conselho Nacional de Educação - Câmara de Educação Superior, por meio da Resolução CNE/CES 3/2001 e publicada no Diário Oficial da União/Brasília, em 9 de Novembro de 2001. Seção 1, p. 37, direciona a reflexão sobre a necessidade de reestruturação curricular (BRASIL, 2001). A formação profissional dos enfermeiros numa visão generalista e humanizada é consequência destas diretrizes (OGG; PAGANINI, 2008). 
As autoras op cit, prosseguem destacando que:

\begin{abstract}
Nesta modalidade, o graduando é preparado para ser capaz, mediante o aprendizado, de atender as exigências gerais e específicas da formação acadêmica, observando fatores humanos, técnicos e administrativos descritos na proposta pedagógica da instituição. Além disso, é estimulado a estabelecer novas relações com o contexto social, suas transformações e expressões, buscando o sentimento de responsabilidade que é requisito para a coordenação de uma equipe de trabalho (OGG; PAGANINI, 2008, p. 24).
\end{abstract}

A educação em enfermagem é construída de acordo com os limites e possibilidades de seu espaço histórico-cultural, que não é estático e está sujeito a transformações contínuas. A educação em enfermagem é apreendida, portanto, como produto de uma multiplicidade de processos sociais que resultam, historicamente, da prática da categoria e dos conjuntos sociais onde essa prática se desenvolve, modificando-se dinamicamente e ajustando-se à evolução da sociedade, de acordo com as exigências da categoria e do setor de saúde. Sob essa ótica, situamos a educação em enfermagem não como algo idealizado, abstrato, mas como parte e como produto do processo de construção da enfermagem (ERDMANN; FERNANDES; TEIXEIRA, 2011).

A expansão de cursos de enfermagem teve início paralelamente aos demais cursos de ensino superior, a partir de 1968, com a lei 5540 - Lei da Reforma do Ensino Superior, que também institucionalizou a pós-graduação em dois níveis - mestrado e doutorado. Seu objetivo consistia em suprir o ensino de graduação em pessoal qualificado, de estimular estudos e pesquisas, além de atender às exigências de um mercado de trabalho que, baseado na sofisticação tecnológica do desenvolvimento industrial, requeria um número crescente de profissionais qualificados (FERNANDES, 1988).

Erdmann, Fernandes e Teixeira (2011), ressaltam que nesta época o desenvolvimento econômico, tecnológico, político, social e cultural do país apontava, à época, para a necessidade do aumento do número de brasileiros com um nível de instrução mais elevado. Esse processo expansionista, por sua vez, vem exigir maior formação do corpo docente, respondendo às necessidades de especialização para atender à área tecnológica e a uma demanda maior do processo produtivo, além de enfrentar as influências das universidades estrangeiras.

Esta situação levou a aprovação da Lei de Diretrizes e Bases da Educação Nacional (LDB) que viabilizou a ampliação quantitativa de Instituições de Ensino Superior e de aumento de vagas (BRASIL, 1996). Essa lei, também, sinalizou a possibilidade de mudanças, pela introdução de opções de ordem organizacional, curricular e de autonomia no panorama do setor educacional. A LDB, viabilizando a criação de cursos, possibilitou a privatização do ensino, com a autonomia dada às instituições de ensino superior e a flexibilização dos currículos, além de direcionar a construção das diretrizes curriculares nacionais para os cursos de graduação (FERNANDES, 2001).

Para Amâncio-Filho (2004), a enfermagem atual vivencia um triplo desafio. Primeiro, 
manter um padrão de qualidade compatível com as exigências do mundo contemporâneo e com o desenvolvimento científico, tecnológico e inovador da área, incorporando os avanços pedagógicos contemporâneos. Segundo, propiciar aos alunos a capacidade de aprender, de trabalhar em equipe, de comunicar-se, de ter agilidade frente às situações adversas e de ter capacidade propositiva. Terceiro, desenvolver atividades relevantes, com características interdisciplinares, capazes de contribuir para a solução de problemas nacionais e para a formação de indivíduos criativos, críticos, empreendedores e, sobretudo, cidadãos comprometidos com a ética da causa pública.

Refletindo sobre estes desafios da enfermagem, enquanto acadêmicos do $7^{\circ}$ período da graduação em Enfermagem, do Centro de Ensino Superior de Valença (CESVA), observamos, ao iniciar o Internato no Pronto Atendimento do Hospital Escola Luiz Gioseffi Jannuzzi, a dificuldade do grupo em lidar com determinadas situações que exigem tomada de decisão do enfermeiro. Uma destas situações foi a parada cardiorrespiratória (PCR).

Pires et al (2006) definem PCR como a cessação da circulação e da respiração, sendo reconhecida pela ausência de pulso e pela parada respiratória em um paciente inconsciente. Este evento representa uma grave emergência clínica, a falta de conhecimento e habilidade dos profissionais envolvidos no atendimento à PCR, a falha na organização do atendimento, assim como provisão insuficiente de materiais e equipamentos necessários para realização das medidas de reanimação favorece a ocorrência de falhas no decorrer da assistência aos pacientes em PCR. O conhecimento e atualização quanto às recomendações das novas diretrizes da Reanimação Cardiopulmonar (RCP) são essenciais para reduzir a mortalidade associada a PCR (SILVA et al, 2010).

Nesse momento, a capacidade de tomada de decisão do enfermeiro é fundamental para garantir as chances de recuperação do doente. A tomada de decisão, portanto, é um processo que envolve aspectos individuais e sociais, sendo necessário que se tenha uma meta, um objetivo ao qual se pretende chegar, para que então se escolha uma ou mais alternativas para o alcance da proposição.

Ainda segundo Cunha (1991 p. 34), “a tomada de decisão é uma atitude que requer consciência da situação como um todo, seja durante uma fração de segundos, seja num período mais longo" pois o processo decisório começa antes do momento da decisão e termina depois dela.

Estudiosos sobre o processo de tomada de decisão afirmam que "as melhores decisões são tomadas quando percorremos todas as fases do processo decisório, de modo sistemático, e que podemos aprender a fazer isso, adquirindo maior segurança” (CIAMPONE, MELLEIRO, 2005, p. 38).

No processo de tomada de decisão, o enfermeiro exerce o controle dos aspectos técnicos de 
seu trabalho, delimitando o que é próprio da enfermagem, para escolher a melhor maneira de atuar no cuidado ao paciente (MERIGH, 2002). Para Lunardi et al (2007) a tomada de decisão faz com que o Enfermeiro exerça sua autonomia e o auxilia no cotidiano de seu trabalho durante o enfrentamento de dilemas e conflitos morais.

Apesar de este conteúdo ter sido contemplado na disciplina Atenção ao Paciente Crítico, que foi ministrada no último ano do curso, mesmo assim, sentimos necessidade de um aprofundamento nesta temática. É necessário que outras disciplinas também abordem este conteúdo, para que o discente tenha mais segurança, raciocínio crítico e capacidade de atuação em uma situação crítica, como é uma PCR.

Corrobora este pensamento Vargas (2006, p.25) quando afirma que:

A existência de lacunas na formação de acadêmicos de enfermagem, aliadas às dificuldades
apresentadas em relação à teoria e a prática nas situações que envolvem a emergência em
uma unidade hospitalar, o despreparo prático em estar atuando na unidade de emergência.
Com isso consideramos que a falta de treinamentos específicos, estágios e cursos
extracurriculares se fazem necessários para ampliar conhecimento, garantindo melhor
assistência dos acadêmicos ao atendimento em uma unidade de emergência.

Valadares (2006) enfatiza que “a PCR é uma das situações enfrentadas pelos enfermeiros, independente da sua área de atuação, pois é uma emergência que pode ocorrer em qualquer ambiente. Essa emergência, além de grave, é decisiva, pois necessita de ação imediata da equipe de enfermagem, não havendo demanda administrativa ou assistencial de qualquer natureza que a ela se oponha em ordem de prioridade".

Silva, Sanna e Nunes (2001) em seu estudo, salientam que é necessário incentivar as faculdades e instituições de saúde a implantarem conteúdos programáticos de sua natureza (emergência) nos cursos de graduação, extensão e treinamento, além de oferecerem atualização continua para profissionais que já estão no mercado de trabalho.

A enfermagem, segundo o Código de Ética Profissional (2007), é considerada uma profissão de atuação social comprometida com a saúde e qualidade de vida da pessoa, família e coletividade. O enfermeiro, entre os três níveis de formação e atuação, assume o papel de líder e toma as decisões referentes ao cuidado. Portanto, cabem às escolas formar profissionais capazes de distinguir na teoria os subsídios necessários para a prática, mas que a prática possa ser campo de reforço contínuo para o aprendizado (OGG; PAGANINI, 2008).

A motivação de realizar uma pesquisa sobre o significado da PCR para o graduando de Enfermagem surgiu ao ingressar no Internato devido a uma expectativa entre os alunos sobre como atuar efetivamente nesta situação. Existiam comentários entre os acadêmicos que já haviam vivenciado essa experiência e estes eram algumas vezes, agradáveis e outras desagradáveis diante da experiência. 
De acordo com Capovilla (2002, p.20)

Na formação do enfermeiro, os conteúdos teóricos e práticos relacionados à PCR e manobras de RCP têm sido ministrados de forma superficial, limitados e, muitas vezes não supre as necessidades dos alunos.

Landers (2000 apud BELLAN et al., 2010) corrobora este pensamento ao afirmar que as dificuldades refletirão na prática do enfermeiro, pois só a experiência profissional não oferece subsídios e embasamentos teóricos suficientes para suprir este déficit.

Nesse sentido, emerge a questão norteadora da pesquisa: qual o conhecimento do acadêmico de enfermagem acerca da atuação do enfermeiro em uma PCR?

Para responder esta questão o estudo tem por objetivo apontar o conhecimento de internos de Enfermagem do CESVA sobre a atuação do enfermeiro durante uma PCR.

Esperamos, com este estudo, contribuir para a formação de indicadores para uma política nacional de formação e capacitação de enfermeiras (os) adequada às exigências do desenvolvimento científico, tecnológico e inovador da área.

\section{Abordagem Metodológica}

Estudo exploratório, transversal, com abordagem quanti-qualitativa.

O estudo é de natureza exploratória quando envolve levantamento bibliográfico, entrevistas com pessoas que tiveram (ou tem) experiências práticas com o problema pesquisado e análise de exemplos que estimulem a compreensão. Possui ainda a finalidade básica de desenvolver, esclarecer e modificar conceitos e ideias para a formulação de abordagens posteriores. Dessa forma, este tipo de estudo visa proporcionar um maior conhecimento para o pesquisador acerca do assunto, a fim de que esse possa formular problemas mais precisos ou criar hipóteses que possam ser pesquisadas por estudos posteriores (GIL, 1999).

O local de realização da pesquisa foi o curso de Enfermagem do CESVA, na cidade de Valença, no Estado do Rio de Janeiro.

Os sujeitos deste estudo foram os graduandos de enfermagem do $8^{\circ}$ período. A opção por estes alunos se deve por ser o perído que já teve a disciplina que aborda a PCR. Como critério de inclusão, participaram somente os alunos regularmente matriculados, no quarto ano do curso e que concordaram em participar do estudo fazendo a assinatura do Termo de Consentimento Livre e Esclarecido (Apêndice I) após tomar ciência dos objetivos da pesquisa. O trabalho foi aprovado pelo Comitê de Ética em Pesquisa da Faculdade de Medicina de Valença, CAAE: 07667512.5.0000.5246 (Anexo 1).

O critério de exclusão foi trabalhar ou já ter trabalhado na Enfermagem. O instrumento de coleta de dados utilizado foi um questionário com 10 questões objetivas no formato de múltipla escolha e cada questão apresentava apenas uma alternativa correta. O valor total do formulário é de 
dez pontos sendo o valor de cada questão 1,0 ponto. Somente os alunos que atingiram pelo menos $85 \%$ de acertos, foram considerados com nível satisfatório de conhecimento, isto é, seria aprovado. Cabe lembrar que esse é o percentual mínimo preconizado como satisfatório nos cursos de Suporte Básico de Vida (BLS) ministrado pela American Heart Association (AHA).

O questionário aplicado aos alunos para verificar o nível de conhecimento adquirido versou sobre os seguintes conteúdos: definição e identificação de PCR, mudança na sequência da RCP, tempo de intervenção, compressões cardíacas e utilização correta do DEA.

A correção das questões foi baseada nas orientações do atual Guideline (ILCOR, 2010).

\section{Resultados e Discussão}

De uma população de 49 alunos, 10 contemplaram o critério de exclusão, pois, trabalham na área de saúde, 4 alunos não quiseram participar da pesquisa e, 3 são os autores do estudo. Nesse sentido, a amostra foi composta por 32 graduandos de enfermagem.

Para apresentação dos resultados do conhecimento teórico dos alunos foi realizado um agrupamento de questões por assunto, sendo eles as manobras de ressuscitação, as questões sobre o DEA e questões sobre definições e conceitos de RCP e PCR.

Os conteúdos das questões do formulário foram agrupados nas Tabelas a seguir para melhor apresentação das respostas dos alunos.

Nas questões relacionadas à definição, identificação e avaliação inicial de uma vítima em PCR apresentadas na Tabela 1, verificou-se que o conteúdo com maior número de respostas incorretas foi em relação a como definir uma parada cardíaca (Tabela 1).

Tabela 1. Distribuição das respostas sobre definição, identificação e avaliação de uma PCR. Valença, $2012(n=32)$

\begin{tabular}{ccccc}
\hline & \multicolumn{2}{c}{ Corretas } & \multicolumn{2}{c}{ Incorretas } \\
Conteúdos & Total & \% & Total & \% \\
\hline Definição & 25 & 78,1 & 07 & 21,8 \\
Identificação & 30 & 93,7 & 02 & 6,2 \\
Avaliação & 30 & 93,7 & 02 & 6,2 \\
\hline
\end{tabular}

Fonte: dados da pesquisa

Cabe ressaltar que, aparentemente, a dificuldade dos alunos parece ser mais uma questão conceitual, a definição de PCR está menos solidificada em seus conceitos do que as ações a serem tomadas. Observa-se que a grande maioria sabe identificar e realizar a avaliação inicial de uma vítima em PCR. Mais ainda, realizar as manobras iniciais. Estes resultados vão de encontro ao estudo de Boaventura (2008), onde apenas 26\% dos alunos tinham conhecimento de como é detectada uma PCR e 13,2\%, apenas, sabiam qual a conduta imediata após uma PCR. Entende-se 
que esta diferença pode ser atribuída a grade curricular do curso de Enfermagem do CESVA, que apesar de ter uma formação generalista do profissional Enfermeiro, contempla este conteúdo, na disciplina Atenção ao Paciente Crítico, ministrada atualmente no $8^{\circ}$ período do curso.

Para Capovilla (2002), na PCR, a atuação do enfermeiro na tomada de decisões rápidas e precisas é imprescindível para garantir o suporte básico de vida e a organização da equipe de atendimento. Isso reporta à necessidade de se repensar a formação acadêmica do enfermeiro, fundamentalmente em situações de emergência.

Diante disso, esse problema sugere que a falta de conhecimento do enfermeiro sobre a PCR/RCP possa estar vinculada à sua formação acadêmica, o que conduz à reflexão sobre a formação desse profissional. Ao se repensar a formação do enfermeiro, parece importante questionar qual o conteúdo de PCR/RCP que está sendo ministrado nos cursos de graduação de enfermagem, bem como a maneira com que o processo de ensino-aprendizagem desse conteúdo está se desenvolvendo.

Os conhecimentos dos graduandos de Enfermagem, no que tange às questões relacionadas à nova sequência da RCP, prevenção de lesão cerebral e frequência das compressões torácicas, estão apresentados na Tabela 2.

Tabela 2. Distribuição das respostas sobre nova sequência na RCP, tempo determinante para evitar lesão cerebral e frequência das compressões. Valença, $2012(\mathbf{n}=32)$

\begin{tabular}{ccccc}
\hline Conteúdos & Total & \% & Total & Incorretas \\
\hline Sequência & 24 & 75 & 8 & 25 \\
Tempo & 10 & 31 & 22 & 69 \\
$\begin{array}{c}\text { Frequência das } \\
\text { Compressões }\end{array}$ & 13 & 41 & 19 & 59 \\
\hline dados da pesquisa & & &
\end{tabular}

Fonte: dados da pesquisa

Verifica-se que os graduandos possuem conhecimento acerca da mudança na sequência de A-B-C para C-A-B. O Guideline 2010 preconiza esta mudança devido à ampla maioria de paradas cardíacas que ocorrem em adultos, onde os elementos iniciais críticos de Suporte Básico à Vida são compressões no tórax e desfibrilação, a sequência de BLS de A (vias aéreas) - B (respiração) - C (Circulação de Compressões) foram alterados para C-A-B pela ILCOR e AHA. Isto é para assegurar que as compressões no tórax serão iniciadas mais cedo enquanto o sangue ainda estiver bem oxigenado. Após 30 compressões, 2 ventilações são realizadas. Isto também é recomendado para bebês e crianças (mas não para recém nascidos).

Entretanto, os graduandos parecem ter ainda muitas dúvidas no que diz respeito ao tempo 
determinante para iniciar as manobras evitando a lesão cerebral por hipoxemia. Estes resultados apontam para a necessidade do conteúdo da disciplina dar um enfoque maior acerca do início precoce das manobras de RCP. Demonstrar para os discentes que quando o início das manobras de reanimação for realizado tardiamente é possível restabelecer as funções vitais por algum tempo, mas a lesão cerebral grave e irreversível que se instala em decorrência da demora do atendimento estará determinando a futura qualidade de vida do indivíduo.

Erecinska e Silver (2001 apud RECH et al., 2006) explicam que a lesão neurológica permanente é a complicação mais temida da reanimação cardíaca prolongada. As altas necessidades energéticas do cérebro humano, se comparadas as suas baixas reservas, tornam-no especialmente vulnerável a situações de isquemia. O cérebro de um adulto corresponde a $2 \%$ da massa corporal total e recebe $20 \%$ do débito cardíaco. Sob condições normais, o metabolismo aeróbico é a maior fonte de energia do cérebro. A parada da circulação cerebral cessa o metabolismo aeróbico em 20 segundos, levando o indivíduo à perda da consciência. Em 5 minutos de completa anóxia cerebral, reduz-se a oferta de oxigênio ao cérebro abaixo de níveis críticos, o que bloqueia o fosforilação oxidativa, diminuindo drasticamente os níveis celulares de ATP; os níveis de glicose também são consumidos e alterações secundárias à isquemia começam a se desenvolver. A atividade neuronal cessa e, se a oferta de oxigênio não for rapidamente restaurada, a célula morre (ERECINSKA; SILVER, 2001 apud RECH et al., 2006). A anóxia produz despolarização das membranas celulares, com influxo de cálcio e acidose lática. O colapso do gradiente iônico resulta na liberação inapropriada de neurotransmissores. Aminoácidos excitatórios como glutamato podem mediar a morte celular. O estresse oxidativo induzido pelos radicais livres é um indicador da resposta inflamatória, que acaba produzindo lesão neurológica adicional (RECH et al., 2006).

No que diz respeito a frequência das compressões torácicas,os dados apontam para uma lacuna no conhecimento destes graduandos, onde a maioria errou a questão que se referia a esta temática. Tal fato pode ser justificado por Silva (2010): “... o que era considerado um aliado no atendimento de emergência em caso de parada cardíaca, agora é visto como prejudicial'. O mesmo autor prossegue afirmando que a massagem cardíaca sozinha é mais eficaz na RCP. Essa mudança de conduta faz parte das novas diretrizes do ILCOR (Aliança Internacional dos Comitês de Ressuscitação), que passaram a valer em 2010, em todo mundo.

Acredita-se que uma das grandes dificuldades para a adesão ao novo Guideline, Sempre foi ensinado em qualquer atendimento a indivíduos em parada cardiorrespiratória que a abertura da via aérea (deslocar a cabeça para trás e puxar a mandíbula) seguida de ventilação boca a boca ou com máscara provida de balão (AMBU) seria a técnica principal a ser adotada antes de iniciar a compressão torácica - massagem cardíaca. Entretanto, novos estudos constatam que a taxa de 
sobrevivência é três vezes maior em pessoas submetidas apenas a compressão torácica do que ventilação e compressão intercaladas (SILVA, 2010).

Tendo em vista a mudança do protocolo de RCP no Guideline 2010, é evidente a necessidade do conhecimento por parte da equipe de saúde, destas mudanças, o que inclui o acadêmico de enfermagem. No âmbito hospitalar, a equipe de enfermagem (incluindo o acadêmico em seu campo de estágio), na maioria das vezes, é a primeira a presenciar uma PCR, pois permanece maior tempo com o paciente, em sua assistência integral.

Segundo Moule (apud LIMA 2009, p.631),

Os profissionais necessitam ter conhecimento técnico atualizado e habilidades práticas desenvolvidas a fim de contribuírem, de forma mais efetiva, no reconhecimento dos sinais de uma PCR, assim como a realização das manobras tradicionais de RCP para que haja uma intervenção eficaz.

Chellel (2000) afirma que o enfermeiro em situações de urgência como a PCR deve ser capaz de tomar decisões e de executá-las, além de estabelecer prioridades com base em seus conhecimentos científicos.

Nas questões relacionadas aos ritmos chocáveis na PCR, quando suspender a RCP a importância do DEA na RCP, os resultados estão apresentados na Tabela 3.

Tabela 3. Distribuição das respostas sobre os ritmos chocáveis, suspensão da RCPe importância do desfibrilador em uma PCR. Valença, $2012(n=32)$

\begin{tabular}{ccccc}
\hline Conteúdos & Total & \% & Total & Incorretas \\
\hline Ritmo chocável & 18 & 56,3 & 14 & 43,7 \\
Suspensão da RCP & 01 & 3 & 31 & 97 \\
Desfibrilador & 32 & 100 & 0 & 0 \\
\hline
\end{tabular}

Fonte: dados da pesquisa

Percebe-se na tabela acima que ainda existe uma certa dificuldade dos alunos na suspensão da RCP.

No que diz respeito à atuação em uma PCR, considerada uma grave emergência clínica, Silva et al (2010) afirma que a falta de conhecimento e habilidade dos profissionais envolvidos no atendimento à PCR, a falha na organização do atendimento, assim como provisão insuficiente de materiais e equipamentos necessários para realização das medidas de reanimação favorecem a ocorrência de falhas no decorrer da assistência aos pacientes em PCR.

O conhecimento e a atualização quanto às recomendações das novas diretrizes da RCP são essenciais para reduzir a mortalidades associada a PCR. A ênfase maior das Diretrizes 2010 é a 
necessidade de uma RCP de alta qualidade, o que inclui, frequência de compressões mínima de 100 minutos (em vez de "aproximadamente" 100/minuto, como era antes), profundidade de compressão mínima de $5 \mathrm{~cm}$ em adultos, retorno total do tórax após cada compressão, minimização das interrupções nas compressões torácicas e evitar excesso de ventilação.

Desse modo para ser eficaz, a RCP deve ser capaz de restaurar os fluxos sanguíneos coronários e cerebrais de maneira adequada. Interrupções nas compressões do tórax diminuem a pressão de perfusão coronária e diminuem os índices de sobrevida a uma parada cardíaca. Nos primeiros minutos da parada cardíaca súbita causada por fibrilação ventricular, a ventilação parece não ser tão importante quanto às compressões torácicas (PIRES, et al 2006). Com este atendimento, o paciente pode recuperar as funções vitais e, na sequência, será atendido pela equipe multiprofissional, a fim de estabilizar a função cardiorrespiratória e intervir na situação patológica que deu origem à PCR. De um modo geral, a assistência de enfermagem durante a PCR deverá ser sempre rápida, segura e com qualidade no atendimento, visando obter a restauração das funções vitais do paciente.

\section{Conclusão}

Várias Escolas de Enfermagem englobam nos seus currículos conteúdos para aprendizagem relacionados com o Suporte Básico de Vida (SBV) e o Suporte Avançado de Vida (SAV). No entanto, percebe-se nas falas de acadêmicos a insegurança para atuarem em situações de emergência, principalmente em casos de PCR.

À medida então que se amplia o espaço de atuação profissional do Enfermeiro, também faz emergir a necessidade contínua de melhorar a formação dos profissionais de saúde. O futuro enfermeiro deverá ter domínio do conhecimento teórico aliado à prática para que saiba identificar o paciente que se encontra em PCR. Buscando sempre uma sintonia com sua equipe visando uma tomada de decisão rápida, estabelecendo ações imediatas.

Diante dos resultados deste estudo, percebe-se que apesar da grade curricular contemplar uma disciplina que aborda o suporte básico de vida, com conteúdo teórico e prático, os acadêmicos apresentam um déficit de conhecimento em relação às novas diretrizes do novo Guideline. Sugerimos que este conteúdo seja inserido em outras disciplinas como, por exemplo: Enfermagem na Saúde do Adulto e Enfermagem na Saúde da Criança, dentre outras. Outra sugestão é que se abra espaço as metodologias ativas de ensino aprendizagem (MAEA), na verdade métodos ativos de ensino-aprendizagem (MITRE et al., 2008) as quais pertencem a uma nova cultura pedagógica, cuja premissa é o estímulo aos estudantes para a construção do próprio conhecimento, desenvolvendo habilidades específicas e a capacidade para identificar e encontrar soluções para os problemas, 
tendo por base o método científico, o trabalho em equipe e a elevada consideração ao contexto social e ambiental das pessoas.

A reflexão sobre o ensino em enfermagem, a nível de graduação, deve estimular os cursos a se perceberem nesse processo e a reverem suas decisões pedagógicas à luz do novo paradigma da formação/capacitação do profissional de saúde, sustentado no modelo de atenção à saúde, preconizado pelo Sistema Único de Saúde (SUS) e centrado na ciência, tecnologia e inovação em enfermagem. O Ministério da Educação (MEC), através das DCN, publicadas em 2001, tem destacado a necessidade de se adotar propostas pedagógicas inovadoras, objetivando um ensino mais orientado para a formação cidadã, o que pressupõe um estudante autônomo e responsável pela construção do próprio conhecimento (BRASIL, 2001).

\section{REFERÊNCIAS}

AMÂNCIO-FILHO, A. Dilemas e desafios da formação profissional em saúde. Rev. Interface Comunicação, Saúde e Educação, n.8, v.15, p.375-80, 2004.

BELLAN, M. C.; ARAUJO, I. I. M.; ARAUJO, S. Capacitação teórica do enfermeiro para o atendimento da parada cardiorrespiratória. Rev. Bras. Enferm., Brasília, v.63, n.6, Dec. 2010. Disponível em: . Acesso em: 29 Apr. 2012.

BOAVENTURA, A.P. Registro do atendimento da parada cardiorrespiratória no ambiente intrahospitalar: validade e aplicabilidade de um instrumento. Rev Gaúcha Enferm., Porto Alegre, v.27, n.3, p.434-42, 2006.

BRASIL. Ministério da Educação. Lei no 9394 de 20 de dezembro de 1996: estabelece as diretrizes e bases da educação nacional. Brasília: Diário Oficial da União; 1996. Dez 23;34(248). Seção 1:27.833-41.

BRASIL. Ministério da Educação (BR). Secretaria de Educação Superior. Diretrizes Curriculares para os Cursos de Graduação. Resolução CNE/CES n 3, de 7 de novembro de 2001. [online]. Disponível em: http://www.mec.gov.br/sesu/diretriz.htm .Acesso em 28 maio 2012.

CAPOVILLA, N.C. Ressuscitação cardiorrespiratória: uma análise do processo ensino/aprendizagem nas universidades públicas estaduais paulistas [dissertação]. Campinas: Faculdade Ciências Médicas, Universidade Estadual de Campinas; 2002.

CIAMPONE, M. H.T; MELLEIRO, M.M. O planejamento e o processo, decisório como instrumentos do processo de trabalho gerencial. In:TROCHIN, D. M. R. et al. Gerenciamento em Enfermagem. 4. ed. Porto Alegre: Artmed, 2005.

CUNHA, M. F. N. da. A pedagogia holística face às exigências de uma nova educação. Rio de Janeiro, Téc. Educ. v.20, p.34-7, 1991. 
CHELLEL, A. the role of nurse in resuscitation attemps in hospitals. Resuscitation: A Guide for Nurses . London : Churchill Livingstone, cap.4, p 33-48, 2000.

Código de Ética dos Profissionais de Enfermagem - COFEN. Rio de Janeiro, 08 de fevereiro de 2007.

DAL SASSO, G. T. M.; SOUZA, M. L. A simulação assistida por computador: a convergência no processo de educar-cuidar da enfermagem. Texto contexto - Enf., Florianópolis, v. 15, n. 2,June 2006 . Disponível em: . Acesso: em 25 Mar. 2012.

ERDMANN, A.L.; FERNANDES, J.D.; TEIXEIRA, G.A. Panorama da educação em enfermagem no Brasil: graduação e pós-graduação. Rev. Enfermagem em Foco, n.2, p.89-93, 2011.

FERNANDES, J.D. Expansão do ensino de enfermagem no Brasil [tese]. Salvador: Escola de Enfermagem da Universidade Federal da Bahia, 1988.

. A trajetória do ensino de graduação em enfermagem no Brasil.

In: Teixeira E, Vale EG, Fernandes JD, Sordi MRL, organizadores. Brasil. Ministério

da Educação. Conselho Nacional de Educação. Câmara de Educação Superior.

Resolução CNE/CES no 3 de 7/11/2001: Diretrizes Curriculares Nacionais do Curso de Graduação em Enfermagem. Brasília (DF); 2001.

GIL, A.C. Métodos e técnicas de pesquisa social. São Paulo: Atlas, 1999

. Como elaborar projetos de pesquisa. São Paulo: Atlas, 2002.

ILCOR MEMBERS ORGANIZATIONS. Guidelines 2010 for Cardiopulmonary Ressucitation and Emergency Cardiovascular Care, Circulation 2010; 102 (suppl-I):86-171.

LUNARDI, V. L. ; LUNARDI FILHO, W. D. ; SILVEIRA, R. S. et al. A ética na enfermagem e sua relação com poder e organização do trabalho . Rev Latino-am Enfermagem 2007 maio-junho 2007; 15(3):493-7.

MARTIN, H. S.; NETO, A. S.; VELASCO, I. T. Emergências clínicas baseadas em evidências. In: DAMASCO, M.T; TIMERMAN, S. Novas técnicas em ressuscitação cardiopulmonar. São Paulo: Atheneu; 2005.

MERIGH, M. A. B. Trajetória profissional das enfermeiras obstétricas. Rev Latino-am Enfermagem 2002 setembro-outubro; 10(5): 644-53.

Moule P, Albarran JW. Automated external defibrillation as part BLS: implications for education and practice. Resuscitation. 2002; 54 (3): 223-30.

MITRE, S. M.; SIQUEIRA-BATISTA, R.; GIRARDI-DE-MENDONÇA, J. M.; MORAIS-PINTO, N. M.; MEIRELLES, C. A. B.; PINTO-PORTO, C.; MOREIRA, T.; HOFFMANN, L. M. A. Metodologias ativas de ensino-apredizagem na formação profissional em saúde: debates atuais. Ciência e Saúde

Coletiva, v. 13, sup. 2, p. 2133-2144, 2008.

NUNES, M.C.C. Atualização sobre a assistência em parada cárdio respiratória. Rev. Gaúcha de Enferm, v.5, n.2, p.279-286, jul, 1994.

OGG, C; PAGANINI, M.C. ENSINO CLÍNICO: significado para o acadêmico de enfermagem; Boletim de Enfermagem; 02; 23 - 35; 2008.

PETERLINI, M. A. S.; HARADA, M. J. C. S.; PEDREIRA, M. L. G.; CARVALHO, W. B.; 
CHAUD, M. N.; LEE, J. H. Reanimação Cardio-Respiratória e Cerebral (RCRC) em pediatria: o conhecimento dos graduandos de Enfermagem. Acta Paul Enf., São Paulo, v.9, n.2, p.68-74, 1996. Disponível em:. Acesso em: 25 Mar. 2012.

PIRES, M. T. B.; REZENDE, N. A.; FERREIRA, C. M. M. P. Reanimação Cardiopulmonar. In: Manual de Urgências em Pronto Socorro. 8 a edição. RJ: Guanabara Koogan; 2006.

RECH, T.H.; VIEIRA, S.R.R; BRAUNER, J.S.Valor da enolase específica do neurônio como indicador de prognóstico pós-parada cardiorrespiratória. Rev. bras. ter. intensiva, São Paulo, v. 18, n. 4, Dec. 2006 . Available from . access on 09 Nov. 2012.

SILVA, A. M. C.; CHAGAS, G. R.; FRANCISCO, J. M. et al. Avaliação do conhecimento sobre diagnóstico e tratamento da parada cardiorrespiratória entre estudantes de fisioterapia da universidade de Taubaté. Rev Bras Fisioter. 2010;14(Supl 1): 316.

SILVA, F. E.; SANNA, M. C.; NUNES, B. Tomada de decisão do enfermeiro frente a uma para cardiorrespiratória. Rev Enferm UNISA 2001; 2: 26-30.

VARGAS, D. Atendimento pré-hospitalar: a formação específica do enfermeiro na área e as dificuldades no início da carreira. Rev Paul Enferm, n.25, v.1, p. 38-43. Março, 2006.

VALADARES, G. V.; VIANA, L. O. A formação profissional e o enfrentamento do conhecimento novo: a experiência do enfermeiro em setores especializados. Rio de Janeiro (RJ): EEAN/UFRJ; 2006. 